Biol. Stud. 2011: 5(1); 45-56 • DOI: https://doi.org/10.30970/sbi.0501.121

www.http://publications.Inu.edu.ua/journals/index.php/biology

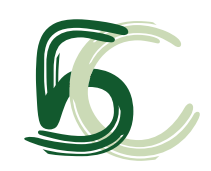

UDC 582.241:502.72:292.451/454(477)

\title{
MYXOMYCETES IN VIRGIN FORESTS OF CARPATHIAN BIOSPHERE RESERVE
}

\section{O. Dudka', D. V. Leontyev ${ }^{2}$}

${ }^{1}$ M. G. Kholodny Institute of Botany of NAS of Ukraine, 2, Tereshchenkivska St., Kyiv 01601, Ukraine e-maili_dudka@mail.ru

${ }^{2}$ Kharkiv State Zooveterinary Academy, 1, Akademichna, Mala Danylivka, Kharkiv62341, Ukraine e-mail: protista@mail.ru

During the mycological observation of beech and spruce-fir virgin forests in the different localities of Carpathian biosphere reserve, carried out in spring and autumn 2006, 18 species, two varieties and one form of Myxomycetes were found. Collected species of myxomycetes present all the orders of class Myxomycetes. The highest species diversity was shown by the order Trichiales and family Trichiaceae, represented in virgin forests by seven species and two varieties. Among revealed myxomycete species Metatrichia floriformis (Schwein.) Nann.-Bremek., collected in beech virgin forest of Uholsko-Schyrokoluzhansky Massif (Mala Uholka) is the second record for Ukrainian mycobiota. Previous record was made by professor of Lviv university $\mathrm{H}$. Krzeminiewska in 1934 in the Chornohora forests. Another rare myxomycete species from virgin forests are: Fuligo intermedia T. Macbr., known in Ukraine as two records only at the Left-Bank (in national nature park „Sviati Hory” and Luhans'k nature reserve); Physarum robustum (Lister) Nann.-Bremek., found in spruce-fir forest of Chornohora near grassland Bretskul, the new species for the Ukrainian Carpathians; Trichia decipiens (Pers.) T. Macbr. var. olivacea Meyl. from beech virgin forest of Mala Uholka - the new variety for the Ukrainian Carpathians. Substrate occurrence of collected myxomycete species was analyzed. It was shown that the majority of multisubstrate species in monodominant beech virgin forests is associated with the dead wood of Fagus sylvatica L.

Key words: Myxomycetes, slime molds, virgin forests, species and taxonomic diversity, substrate occurrence.

\section{INTRODUCTION}

Virgin forests and similar natural forests have a great scientific and practical value. The virgin forest ecosystems should be considered as a kind of "golden phytocoenotical treasure-trove of the biosphere" [26]. At the same time the areas of such forests constantly decrease and will evidently also decrease in future. In Europe, virgin forests are especially valuable because of their rarity. The largest virgin beech (Fagus sylvatica L.) 
forests in Europe are situated in Ukraine, forming the core areas of the Carpathian biosphere reserve (CBR) [12]. The duration of their life cycle is over 250 years, sometimes approaches 300 years.

The Uholsko-Shyrokoluzhansky Massif of the reserve with an area of 15974 ha is covered by almost pure beech forests. Almost 9000 ha are considered to be virgin forests. The part of them is known as the Uholka Massif, which is situated on the southern slope of central part of the Polonina Carpathians within an altitudinal gradient of 400 $1280 \mathrm{~m}$ a.s.l.

The species composition of virgin forests in Uholka is not very diverse: they consist mostly of beech trees. Only insignificant admixture of associated species (3\%) such as Norway maple and sycamore (Acer platanoides L. and Acer pseudoplatanus L., 2.1\%), witch elm (Ulmus glabra Huds., $0.4 \%$ ) and European ash (Fraxinus excelsior L., $0.6 \%$ ) is present. Uholka virgin beech forests are included in the Green Book of Ukraine as the rare forest associations (Ulmeto (glabrae) - Fagetum (sylvaticae) phyllitidosum (scolopendrii), Acereto (pseudoplatani) - Fagetum (sylvaticae) phyllitidosum (scolopendrii), Acereto (pseudoplatani) - Fraxineto (excelsioris) - Fagetum (sylvaticae) phyllitidosum (scolopendrii)) with high synphytosozologic index (11.6-11.8) and the highest conservation category (1), which is characterized by the unique type of dominating species combinations [3].

Taking into account that Carpathian virgin forests ecosystems pass through the complete cycle of development without any anthropogenic interference [10], it may be supposed that much more species of conservation interest can be found here. Therefore, in the frame of scientific collaboration between CBR and Swiss Federal Institute of Forest, Snow and Landscape Researches for the study of biodiversity in Uholka unique beech associations, the inventory plots of 10 ha were established in 2000 . For detailed study of biota and forest renewal process in the Uholka, each 10 ha plot was divided on 0.25 ha subplots. The choice of suitable plot was based on the preliminary observations of some forestry squares, among them diameter and height of beech trees and the mass of dead wood on the area of 0.25 ha. It appears that 21 beech trees per ha had diameter $80 \mathrm{~cm}$ or more (the largest measured was $132.6 \mathrm{~cm}$ thick). Diameters distribution (frequency of trees per $4 \mathrm{~cm}$ diameter classes) on the 10 ha plot in Uholka shows that trees with diameter $56-74 \mathrm{~cm}$ dominate there. The number of trees more than $74 \mathrm{~cm}$ in diameter decreases slowly to $110 \mathrm{~cm}$. The height of beech trees varies in the Uholka plot from prevailing meanings of $40 \mathrm{~m}\left(\mathrm{~d}_{\mathrm{dom}}\right)$ to maximum ones of $50 \mathrm{~m}$ [11].

The first observations on the experimental plot of Uholka virgin beech ecosystems that was called "Swiss tests" were dealt with species diversity of the vascular plants [1]. Fungal diversity was left beyond the attention of scientists, though it was shown the xylobiont fungi were the most numerous and diverse in the virgin forests [13]. Only in 2006 the first results on aphyllophoroid fungi, recorded on the experimental plot of Uholka virgin beech ecosystems, were published [6]. However numerous xylobiont species from other groups of fungi and fungi-like organisms were not included in the investigations. Particularly, Myxomycetes, the diverse and abundant component of forest ecosystems, which develop on woody substrates, were not studied. However, it was shown, that Uholka Massif is very rich of dead wood: upon the average it forms $13 \%$ of the total wood volume (in maximum - up to one third). The relation of standing to lying deadwood in Uholka was 28:72; especially abundant was the wood on final disintegration stage (200(-300) $\left.\mathrm{m}^{3} / \mathrm{ha}\right)$ [11].

ISSN 1996-4536 • Біологічні Студії / Studia Biologica • 2011 • Том 5/№1 • C. 45-56 


\section{MATERIALS AND METHODS}

Taking into consideration that Uholka Massif is rich of the favourable substrate for Myxomycetes (dead wood), study of these organisms was undertaken here in May 2006. Some additional collections were made also in another virgin beech forest, situated near the rocks Grebeni, not far from the "Swiss tests”. To compare the Myxomycetes species richness in various locations of natural beech forests, similar with the virgin ones, and to study the seasonal differences in their species composition, the observations were also carried out in Chornohora Massif of CBR. For this purpose the old beech forest of Keveliv forestry near the mountain pastures Zanoga and Gropa along the road to mountain Petros was chosen. The collection of Myxomycetes specimens was realized there in September 2006. Besides the beech forests Myxomycetes were collected in reserve's spruce-fir forests on the territories of Marmarosh Massif along the Bily Potik at the road to mountain Pip Ivan (August 2006) and of Chornohora Massif near the mountain pasture Bretskul (September 2006). These collections were aimed at evaluation of the difference between the Myxomycetes species compositions that are formed on the dead wood of Fagus sylvatica and Picea abies. The most part of myxomycete specimens has been found on rotten beech wood having fallen down about a decade ago and infected by specific fungal species.

Identification of the collected Myxomycetes specimens was fulfilled with help of the special manuals dealing with this group of organisms [8, 14, 19-21, 23, 24].

Light microscope „Biolam” (magnification $\times 150, \times 300, \times 600, \times 900)$ and binocular microscope "MBS-9" (magnification $\times 7,5, \times 15, \times 30$ ) were used for morphological studies of Myxomycetes sporophore elements that are obligate for exact species identification. Myxomycetes photos were made with digital camera "Canon Power Shot A510"

Classification of Myxomycetes used in the paper is taken from $10^{\text {th }}$ edition of "Ainsworth and Bisby's Dictionary of the Fungi" [9]. Latin names of the Myxomycetes species are given in accordance with the nomenclatural catalogue "Novenmyx. A Nomenclatural Taxabase of Myxomycetes" [18] in agreement with the International Code of Botanical Nomenclature. Abbreviation of author's names corresponds to modern standards [15]. Latin names of vascular plants are presented in accordance with „Vascular Plants of Ukraine. A Nomenclatural Checklist” [22].

\section{RESULTS AND DISCUSSION}

During our observations that was carried out in virgin beech and spruce-fir forests of CBR alltogether 18 species, 2 varieties and 1 form of Myxomycetes were found in five investigated localities. Their list is presented in Table. Taxonomic analysis demonstrated only one species Ceratiomyxa fruticulosa belonging to subclass Ceratiomyxomycetidae. All other species are the representatives of subclass Myxogasteromycetidae which are distributed between four orders: Trichiales (7 species and 2 varieties), Physarales (4), Liceales (4) and Stemonitales (2). Trichiaceae was the dominating (7 species and two varieties) among the families of Myxomycetes recorded in CBR. All representatives of order Physarales belong to family Physaraceae (4 species and one form). The majority of Liceales are members of Tubuliferaceae (three species) and only one is a member of Liceaceae. Stemonitidaceae is presented by two species from Stemonitales. Concerning the genera of collected myxomycetes, we found that Trichia Haller (4 species and two 
varieties) was the most diverse in comparison with other ones. Fuligo Haller (Physaraceae), Lycogala Adans. (Tubuliferaceae) and Metatrichia Ing (Trichiaceae) include two species each. The remaining seven genera: Craterium Trentep. and Physarum Pers. (Physaraceae), Hemitrichia Rostaf. (Trichiaceae), Licea Schrad. (Liceaceae), Tubulifera O.F. Müll. ex Jacq (Tubuliferaceae), Diachea Fr. and Stemonitopsis (Nann.Bremek.) Nann.-Bremek. (Stemonitidaceae) are presented in our collection by single species each.

Myxomycete species found in the Carpathian Biosphere Reserve

\begin{tabular}{|c|c|c|c|c|c|}
\hline \multirow[b]{3}{*}{ SPECIES } & \multicolumn{5}{|c|}{ Location } \\
\hline & \multicolumn{2}{|c|}{ Uholka } & \multicolumn{2}{|c|}{ Chornohora } & \multirow{2}{*}{ 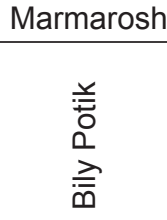 } \\
\hline & $\begin{array}{l}\overline{\frac{1}{0}} \\
\frac{0}{0} \\
\frac{0}{0}\end{array}$ & 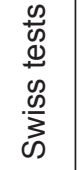 & 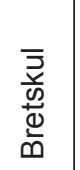 & 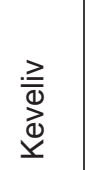 & \\
\hline Ceratiomyxa fructiculosa (Müll.) T.Macbr. & & & & wFS & wPA \\
\hline Craterium cf. minutum (Leers) Fr. & & & & & gr+ \\
\hline Diachea leucopodia (Bull.) Rostaf. & & & & & I+FS \\
\hline Fuligo intermedia T. Macbr. & & wFS & & & \\
\hline F. septica (L.) F.H.Wigg. f. flava (Pers.) Y.Yamam. & & & & wFS & \\
\hline Hemitrichia clavata (Pers.) Rostaf. & & & & wFS & \\
\hline Licea minima Fr. & & & & WPA & \\
\hline Lycogala epidendrum (L.) Fr. & & & & wFS & \\
\hline L. terrestre Fr. & & & & WFS & \\
\hline Metatrichia floriformis (Schwein.) Nann.-Bremek. & wFS & & & & \\
\hline M. vesparia (Batsch) Nann.-Bremek. & wFS & wFS & & & \\
\hline Physarum robustum (Lister) Nann.-Bremek. . & & & wPA & & \\
\hline Stemonitopsis typhina (F.H. Wigg.) Nann.-Bremek. & & & & wFS & \\
\hline Trichia affinis de Bary & & wFS & & wFS & \\
\hline T. decipiens (Pers.) T.Macbr. var. decipiens & & & & wPA & \\
\hline T. decipiens var. olivacea Meyl. & & wFS & & & \\
\hline T. persimilis P. Karst. & & wFS & & & \\
\hline T. varia (Pers. ex J.F.Gmel.) Pers. & & & wPA & wFS & \\
\hline Tubulifera arachnoidea Jacq. & & & & wFS & \\
\hline
\end{tabular}

Legend: wFS - dead wood of Fagus sylvatica, wPA - dead wood of Picea abies, I+FS - fallen leaves of Fagus sylvatica, gr+- dead herbal plants.

Among the species of Myxomycetes collected in CBR virgin forests only four species were recorded from two locations of five studied ones. C. fruticulosa was found in virgin beech forest of Chornohora Massif along the road to mountain Petros near the grasslands Zanoga and Gropa (Keveliv forestry) and in spruce-fir forest of Marmarosh Massif at the road to mountain Pip Ivan along the Bily Potik. Metatrichia vesparia was revealed in two locations of Uholsko-Schyrokoluzanski Massif: in virgin beech forest on 
"Swiss tests" (two specimens) and near the rocks Grebeni (also two specimens). Trichia affinis was presented by two specimens, both collected in virgin beech forests: one from Swiss tests and another - from Keveliv forestry. One specimen of Trichia varia was collected in spruce-fir forest of Chornohora Massif near the mountain pasture Bretskul and two specimens - in virgin beech forests of Keveliv forestry. The others 14 species, two varieties and one form were recorded from one location only. Two of them were presented by two specimens each (Hemitrichia clavata and Metatrichia floriformis).

The most part of recorded myxomycete species are rather wide-spread in various forest types not only in Ukraine but in the world too. At the same time there are some species, which may be valued as a rare components of investigated myxomycete biota of virgin forests. E.g. Metatrichia floriformis, collected in virgin beech forests of Mala Uholka (at the foot of rocks Grebeni) on decaying wood of Fagus sylvatica, is very rare and interesting myxomycete species (Fig.1). First of all, it is the second species of genus Metatrichia in Ukraine; as against $M$. vesparia, which is characterized by the worldwide distribution and high abundance in the forests of all natural zones of Ukraine, $M$. floriformis may be determined as a species with very limited distribution. The first M. floriformis record in Ukraine was dated for 1934 and pertained to H. Krzeminiewska, professor of Lviv university, who had made a great contribution into Ukrainian myxomycetology. She collected Myxomycetes in the Ukrainian Carpathians (mountain ridges Chornohora and Chyvchyn) and in Lviv botanical garden [16, 17]. All H. Krzeminiewska's myxomycete specimens are deposited in herbarium of Ivan Franko Lviv national university (LW). Before our record of M. floriformis in 2006 anybody of mycologists didn't succeed to collect it in Ukraine after $\mathrm{H}$. Krzeminiewska. Therefore we give here the diagnosis of this rare species.
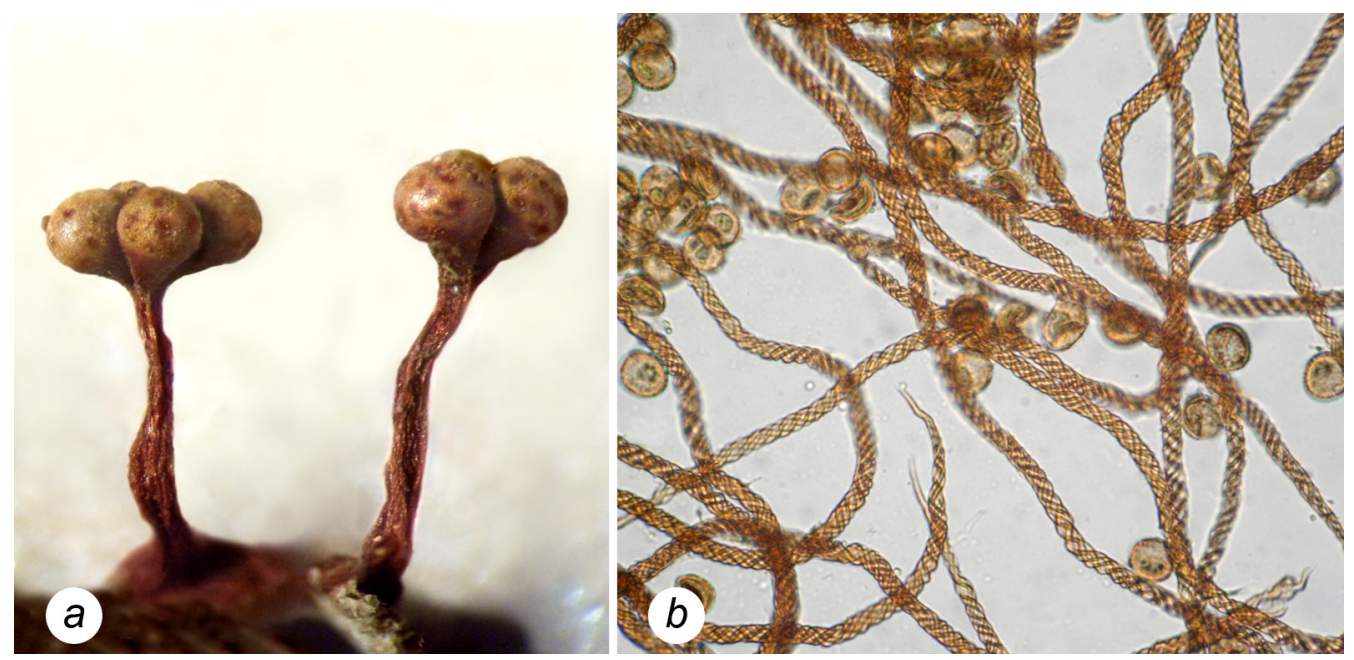

Fig. 1. Metatrichia floriformis (Schwein) Nann.-Bremek.: $a-$ general view of sporocarps, $\times 15 ; b-$ capillitium and spores, $\times 600$

Metatrichia floriformis (Schwein) Nann.-Bremek., Proc. K. Ned. Akad. Wet. Ser. C. - 1982. - 85: 556-557; Trichia floriformis (Schwein.) G. Lister, Journ. Bot., 1919. 57: 110; Craterium floriforme Schwein., Trans. Am. Phil. Soc. - 1832. - II, 4: 258. 
Sporocarps gregarious, stalked, 3-4 mm high, pyriform, drop-like or sphaerical, slightly pressed at the apex, 0.5-0.9(-1) $\mathrm{mm}$ in diameter, brown, often with darker spots on the surface. Stalk from half to one and a half times as long as sporangium, grooved, dark-red, sometimes several (up to nine) stalks are merged into a column. Peridium sturdy, consisting of two tightly connected layers, outer one has thick parts which are alternated with thinner bands; the inner one thin, membranous, dehiscing of both layers happens together along the thinner bands, a basal cap with separate lobes having petaloid margin is formed as a result. Capillitium consists of rust-red tubes, usually unbranched, coiled rope-like around themselves, 5-7 $\mu \mathrm{m}$ in diameter. Spores in mass rusty-red, 10-12 $\mu \mathrm{m}$ in diameter, minutely spinulose.

All material, collected in CBR, was characterised by unusually light surface of sporotheci: the outer peridium was light ochre-brown, with clearly seen darker spots. In the contrary, specimens from West Europe are usually characterized by very dark, almost black peridium with wine-red tint.

Substrate: decaying wood of Fagus sylvatica

Distribution in Ukraine: Zakarpats'ka oblast, Ryachiv district, Carpathian biosphere reserve, virgin beech forest near village Mala Uholka, at the foot of rocks Grebeni, 5-6.05.2006, collector I.O. Dudka

General distribution: Europe (Spain, France, Great Britain, Germany, Poland, Lithuania, Estonia), Russia (Tverskaya obl., Ural, Krasnoyarskiy Kray ), Asia, Northern and Central America, Australia.

Fuligo intermedia (Fig. 2), collected in virgin beech forests of Mala Uholka („Swiss tests") on decaying wood of Fagus sylvatica, is the first record of species at the territory of the right-bank Ukraine. Previously it was known for Ukraine only from two records made in the eastern part of country. At the first time F. intermedia was collected in National nature park „Sviati Hory” (Donetsk oblast). Unfortunately information about this
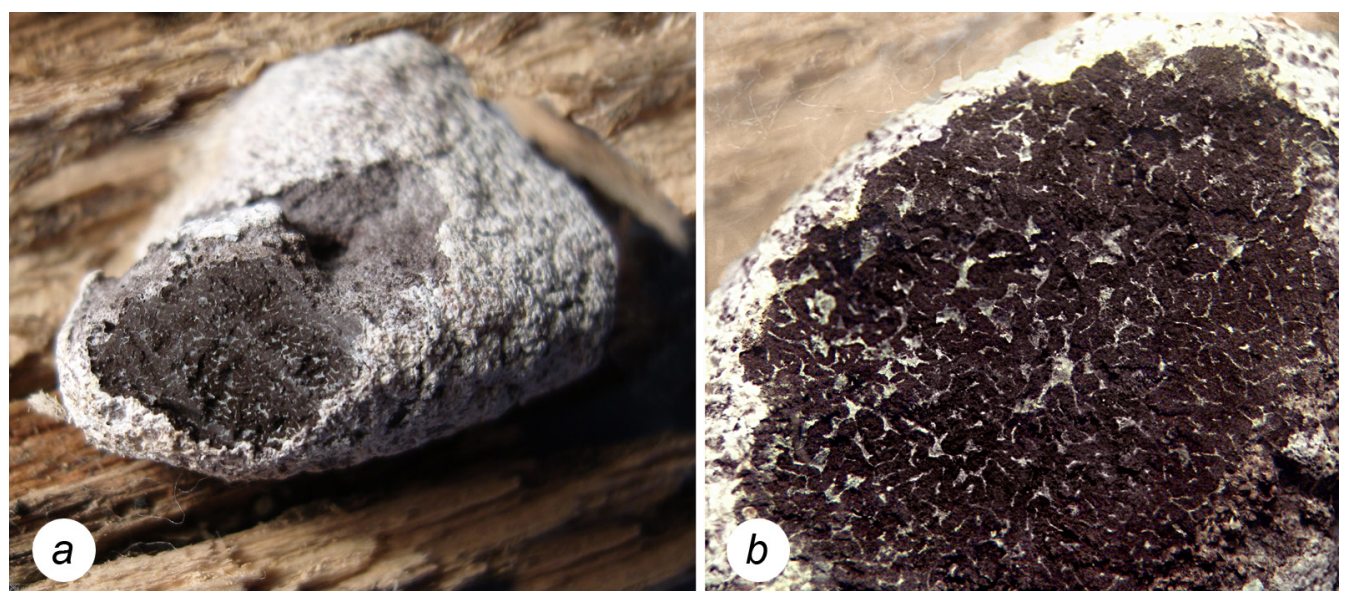

Fig. 2. Fuligo intermedia T. Macbr. : $a$-general view of aethalium, $\times 2 ; b-$ pseudocapillitium and spore mass, $\times 7,5$

record was not published and may be found only in manuscript of "Chronicle of nature" (2008, volume 10) which is supported by scientific staff of National nature park „Sviati Hory" (personal communication of O.Yu. Akulov). Two years later the second specimen

ISSN 1996-4536 • Біологічні Студії / Studia Biologica • 2011 • Том 5/№1 • С. 45-56 
was collected by O.Yu. Akulov at the end of October 2010 in Stanichno-Lugansky department of Luhansky Nature Reserve (Luhansk oblast) and identified by I.I. Morozova [7]. The specimen is preserved in mycological herbarium (CWU Myc) of Kharkiv national university. There are certain morphological characters which allow to distinguish F. intermedia from other species of genus Fuligo. From other 'white' species, F. cinerea (Schwein.) Morgan and F. candida Pers. it may be distinguished on the base of the structure of aethalium cortex and spore sizes: cortex of $F$. intermedia is very thin and wrinkled, but it doesn't crumble, as F.candida cortex does. Comparing F. intermedia and F.cinerea, the spore size may be used as a distinguishing character.

Physarum robustum, observed as a single specimen on decaying wood of Picea abies in spruce-fir forest near the mountain grassland Bretskul (Chornohora Massif of CBR), deserves to be mentioned as a new species for Ukrainian Carpathians. As it was pointed out earlier, Myxomycetes in the forests of Chornohora mountain ridge were carefully investigated by professor $\mathrm{H}$. Krzeminiewska during 15 years (1925-1940) but she hasn't succeed to collect this species. Ph. robustum is absent in her list of Myxomycetes recorded for the Eastern Carpathians [16] and in H. Krzeminiewska's collection deposited in LW. In the contrary, in Europe this species is considered as common and wide-spread; it was recorded also from Japan and New Zeland [14].

Trichia decipiens var. olivacea (Fig. 3) was found on decaying wood of Fagus sylvatica in virgin beech forests of Mala Uholka („Swiss tests”). This variety is known as wide-spread in Europe [14] and quite common in Ukraine. In Mala Uholka („Swiss tests”) it was collected in aberrant form lacking stalk. Because of such unusual form, on the base of macromorphological features the specimen seems to be similar with Prototrichia metallica (Berk.) Massee. However the micropreparations have clearly demonstrated Trichia-type capillitium lacking the penicillate branching which is a specific character for the genus Prototrichia Rostaf. The specimen was sent to Professor U. Eliasson (Denmark) and he identified it as $T$. decipiens var. olivacea, new variety of $T$. decipiens for the Carpathians.
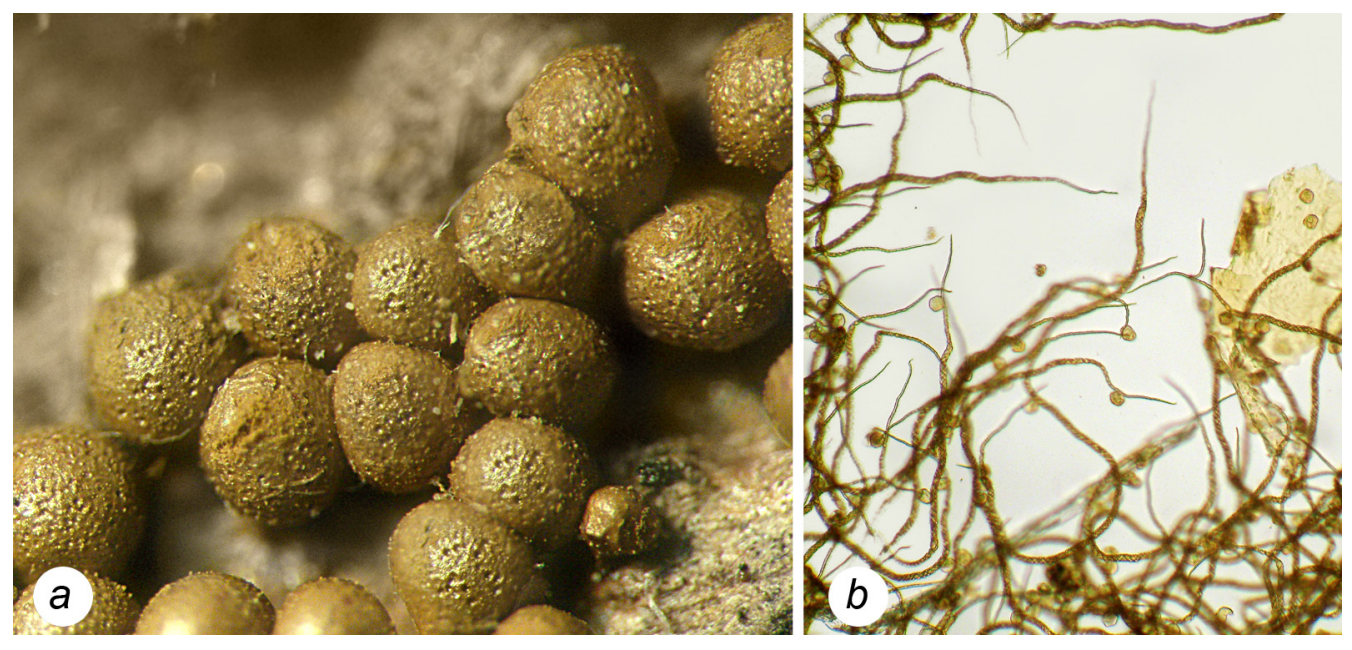

Fig. 3. Trichia decipiens (Pers.) T. Macbr. var. olivacea Meyl.: a - general view of sporocarps, $\times 15 ; b-c a p i l-$ litium and spores, $\times 300$ 
Wood of stumps and logs of different trees at various stages of decomposition is known to be the main substrate for the development of Myxomycetes in forest communities. From 18 species of Myxomycetes collected in virgin forests of CBR only two, Craterium minutum and Diachea leucopodia, were observed on dead grass (the first one) and on decaying leaves of Fagus sylvatica in forest litter (the second one). For other 16 species occurrence on decaying wood of deciduous and coniferous trees was confirmed. Fagus sylvatica was the main woody species that fed the majority of Myxomycetes collected in virgin forests of CBR. The following 14 species were found on wood of F. sylvatica: Ceratiomyxa fruticulosa, Fuligo intermedia, F. septica f. flava, Hemitrichia clavata, Lycogala epidendrum, L. terrestre, Metatrichia floriformis, M. vesparia, Stemonitopsis typina, Trichia affinis, T. decipiens var. olivacea, T. persimilis, T. varia and Tubulifera arachnoidea. 11 of them were collected in CBR on wood $F$. sylvatica only, two ones ( $C$ fruticulosa and T. varia) - on wood of Picea abies too. The wood of $P$. abies is not so frequently inhabited by slime molds: except two above-mentioned species two additional ones, Licea minima and Physarum robustum, were recorded exclusively on this type of substrate. Another variety of $T$. decipiens apart var. olivacea on wood of $F$. sylvatica - var. decipiens - was found in CBR on wood of $P$. abies only. These two varieties deserve a special attention. There is opinion that it is not so easy to distinguish them on the base of morphological characters. For example, B. Ing pointed out that he has only one positively identified specimen of $T$. decipiens var. olivacea in Great Britain but it was rather similar to the type variety $T$. decipiens var. decipiens [14].

It should be noted that the most part of Myxomycetes (13 species) that were collected in CBR virgin forests on one type of wood only (11 species on F. sylvatica and two on $P$. abies) generally belong to multisubstrate species and outside the study area they were found on other types of wood. For example, in Polish nature reserve near Walbrzych C. fruticulosa, H. clavata, L. epidendrum were observed on the wood of Fagus, Tilia, Quercus, Acer, Betula, Carpinus, Picea and Pinus; M. vesparia - on wood of Fagus, Tilia, Quercus and Acer, M. floriformis - on wood of Fagus, Tilia and Picea, S. typhina - on wood of Fagus, Tilia, Acer and Carpinus [25]. There are similar data about the occurrence of overviewed myxomycete species on a great varieties of wooden substrate in various forest types of Ukraine. For example, L. epidendrum was collected on wood of A. platanoides, Alnus glutinosa (L.) Gaertn., Betula pendula Roth, Carpinus betulus L., F. sylvatica, P. abies, Pinus sylvestris L., Populus nigra L., P. tremula L., Quercus robur L, Telycrania sp.; M. vesparia is known from Ukraine on wood of $A$. glutinosa, B. pendula, C. betulus, F. sylvatica, $P$. abies, $P$. sylvestris, $P$. nigra, $P$. tremula, $Q$. robur etc. $[2,4,5]$.

Substrate preferences of two myxomycete species, Craterium minutum and Diachea leucopodia, collected on grass and decaying leaves of $F$. sylvatica correspondingly, is supported by data of polish mycologists [25]. They consider $D$. leucopodia as a member of dominant group of myxomycete species connected with forest litter of deciduous trees. As for $C$. minutum, in their opinion it has to be engaged in group of Myxomycetes connected with decaying leaves in forest litter but as accompanying species developing in smaller quantities.

\section{CONCLUSION}

The results of myxomycete collections carried out in virgin beech forests of CBR at spring and autumn, permit us to make preliminary supposition about the seasonality in

ISSN 1996-4536 • Біологічні Студії / Studia Biologica • 2011 • Том 5/№1 • С. 45-56 
the development of slime molds. Though the virgin beech forests of Mala Uholka („Swiss tests" and rocks Grebeni together) is considered as the most valuable reserve forest ecosystems in Europe which apriori had to be the richest in relation of biodiversity spring observation permit to find six species of slime molds only. The autumn collection realized in reserve beech forests (Chornohora, Keveliv forestry) similar to virgin ones gave higher species diversity of Myxomycetes (11 species). Thus our results confirmed wellknown thesis about the most favourable conditions for myxomycete development in autumn when the differences between diurnal and nocturnal temperatures become considerable and local humidity is slightly higher due to frequent fogs. Such conditions in autumnal beech forests explain the increase of myxomycete species diversity in Keveliv forestry in comparison with the spring list of Myxomycetes in Mala Uholka. However thorough comparative analysis of both myxomycete lists demonstrates that almost all rare and interesting taxa (Metatrichia floriformis, Fuligo intermedia, Trichia decipiens var. olivacea) were collected in Mala Uholka. It means that additional expeditions to virgin beech forests of Mala Uholka and other part of CBR throughout the vegetative season will enrich the information about myxomycete species and taxonomic diversity in these unique ecosystems.

\section{Acknolegements}

The authors thank the Head of Carpathian biosphere reserve Dr Sci F.D. Hamor for assistance in organizing of expedition work and curator of I. Franko Lviv National University herbarium (LW) T.S. Khmil' for help with revision of Prof. H. Krzeminiewska's myxomycete collection.

1. Гамор А.Ф. Порівняльний аналіз флористичного складу постійних пробних площ в букових пралісах Українських Карпат та господарських бучин Швейцарських Альп. Наук. записки державного природознавчого музею. Львів, 2004; 20: 115-121.

2. Дудка И.А., Кривомаз Т.И. Миксомицеты национальных природных парков Украинского Полесья. Микол. и фитопатол, 2006; 40(1): 25-32.

3. Зелена книга України / під заг. ред. чл.-кор. НАН України Я.П. Дідуха. Київ: Альтерпрес, 2009. 448 c.

4. Кривомаз T.І. Таксономічна структура та особливості екології міксоміцетів лісів України: Автореф. дис.... канд. біол. наук: спец. 03.00.21 „Мікологія”. Київ, 2010. 29 с.

5. Леонтьєв Д.В. Міксоміцети національного природного парку „Гомольшанські ліси”: Авторефф. дис.... канд. біол. наук: спец. 03.00.21 „Мікологія”. Київ, 2007. 20 с.

6. Ловас П.С., Куфффер Н. Афрілофоральні гриби букових пралісів Карпатського біосферного заповідника та господарських бучин Швейцарських Альп. Наук. вісник Ужгородського університету. Сер. Біологія, 2006; 19: 60-65.

7. Морозова І.І. Доповнення до видового складу міксоміцетів Луганського природного заповідника. Матеріали V Міжнар. наук. конф. молодих вчених „Біологія: від молекули до біосфери" (22-25 листопада 2010, м. Харків). Харків: Оперативна поліграфрія, 2010: 384-385.

8. Новожилов Ю.К. Определитель грибов России: отдел Слизевики. Вып. І Класс Миксомицеты. СПб: Наука, 1993. 288 с.

9. Ainsworth \& Bisby's Dictionary of Fungi. $10^{\text {th }}$ ed. / P.M. Kirk, P.F. Cannon, J.C. David, D.W. Minter, J.A. Stalpers. - Wallingford: CAB International, 2009. 771 p.

10. Cherniavskyy M.V. Dynamics of Virgin Beech Forest Development. $6^{\text {th }}$ IUFRO Beech Symposium. Program \& Abstracts. Lviv, 1995: 12. 
11. Commarmot B., Bachofen H., Bundziak Y., Bürgi A., Ramp B., Shparyk Y., Sukhariuk D., Viter $R$., Zingg $A$. Structures of virgin and managed beech forests in Uholka (Ukraine) and Sihlwald (Switzerland): a comparative study. For. Snow Landsc. Res, 2005; 79: 45-56.

12. Commarmot B., Duelli P., Chumak V. Urwaldforschung. Beispiel Biosphaerenreservat Transcarpatien. Forum für Wissen, 2000: 61-68.

13. Duelli P., Chumak V., Obrist M.K., Wirz P. The biodiversity values of European virgin forests. For. Snow Landsc. Res, 2005; 79: 91-99.

14. Ing B. The Myxomycetes of Britain and Ireland. An Identification Handbook. Slough: The Richmond Publishing Co. Ltd., 1999. 374 p.

15. Kirk P.M., Ansell A.E. Authors of Fungal Names. A list of authors of scientific names of fungi, with recommended standard forms of their names, including abbreviations. Wallingford: CAB International, 1992. $95 \mathrm{p}$.

16. Krzeminiewska H. Śluzowce Karpat Wschodnich. Kosmos, 1934; 59: 207-223.

17. Krzeminiewska H. Śluzowce zebrane w starym ogrodzie botanicznym we Lwowie. Kosmos, 1937; 62: 17-26.

18. Lado C. Novenmyx. A nomenclatural taxabase of Myxomycetes. Madrid: Cuadenos deTrabajo de Flora Micologica Iberica, 2001. 224 p.

19. Lister A. A Monograph of the Mycetozoa. London: British Museum, 1925. 296 p.

20. Martin G.W., Alexopoulus C.V. The Myxomycetes. lowa City: lowa Univ. Press, 1969. 560 p.

21. Mitchel D.H. Key to corticulous Myxomycetes. Syst. Geogr. PI., 2004; 47: 261-285.

22. Mosyakin S.L., Fedoronchuk M.M. Vascular Plants of Ukraine. A Nomenclatural Checklist. Kiev, 1999. 345 p.

23. Nannenga-Bremekamp N.E. A Guide to Temperate Myxomycota. Bristol: Biopress Ltd., 1991. $410 \mathrm{p}$.

24. Olive L.S. The Mycetozoa. New York; San Francisco; London: Acad. Press, 1975. 293 p.

25. Stojanowska W., Panek E. Myxomycetes of the nature reserve near Wałbrzych (SW Poland) Part II. Dependence on the substrate and seasonality. Acta mycol., 2004. 39 (2): 147-159.

26. Stoyko S. Characteristics of virgin forests of the Ukrainian Carpathians and their significance as an ecological model for natural forest management. In: Cammarmot B., Hamor F.D. (eds.) Natural Forest in the Temperate Zone of Europe - Values and Utilisation. Conference 13-17 October 2003, Mukachevo, Ukraine. Proceedings Birmesdorf, Swiss Federal Research Institute WSL; Rakhiv, Carpathian Biosphere Reserve, 2005: 423-430.

\title{
МІКСОМІЦЕТИ ПРАЛІСІВ КАРПАТСЬКОГО БІОСФЕРНОГО ЗАПОВІДНИКА
}

\author{
I. О. Дудка' ${ }^{1}$ Д. В. Леонтьєв \\ ${ }^{1} /$ нститут ботаніки ім М.Г. Холодного НАН України \\ вул. Терещенківська, 2, Київ 01601,Україна \\ e-mail: i_dudka@mail.ru

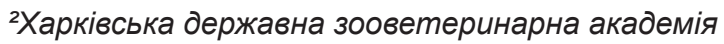 \\ вул. Академічна, 1, Мала Данилівка, Харків 62341, Україна \\ e-mail: protista@mail.ru
}

В ході мікологічного обстеження букових та смереково-ялинових пралісів на різних ділянках Карпатського біосферного заповідника, здійсненого навесні та восени 2006 р., було виявлено 18 видів, два різновиди та одну форму міксоміцетів. У систематичному відношенні зібрані види міксоміцетів розподілилися між порядками Protosteliales, Trichiales, Physarales, Liceales та Stemonitales. Найбільшим видовим 
різноманіттям відзначилися порядок Trichiales та родина Trichiaceae, репрензентовані в пралісах сімома видами і двома різновидами. Серед виявлених видів міксоміцетів Metatrichia floriformis (Schwein.) Nann.-Bremek., зібрана в буковому пралісі Угольсько-Широколужанського лісового масиву (урочище Мала Уголька), є другою знахідкою для мікобіоти України. Попередня знахідка була здійснена професором Львівського університету Г. Кшемєнєвською в лісах Чорногірського масиву в 1934 р. До інших рідкісних видів міксоміцетів належить Fuligo intermedia T. Macbr., раніше відомий в Україні лише з двох знахідок на Лівобережжі (в національному природному парку „Святі гори” та в Луганському природному заповіднику). Physarum robustum (Lister) Nann.-Bremek., знайдений у смереково-ялиновому лісі Чорногори біля полонини Брецкул, є новим видом для Українських Карпат, а Trichia decipiens (Pers.) T. Macbr. var. olivacea Meyl. з букового пралісу Малої Угольки - новим різновидом для Українських Карпат. Здійснено аналіз субстратних уподобань зібраних міксоміцетів. Встановлено, що в умовах монодомінантних букових пралісів переважна більшість зібраних мультисубстратних видів асоційована з мертвою деревиною Fagus sylvatica L.

Ключові слова: Myxomycetes, слизовики, праліси, видове і таксономічне різноманіття, субстратні уподобання.

\title{
МИКСОМИЦЕТЫ КОРЕННЫХ ЛЕСОВ КАРПАТСКОГО БИОСФЕРНОГО ЗАПОВЕДНИКА
}

\author{
И. А. Дудка', Д. В. Леонтьев ${ }^{2}$ \\ ${ }^{1}$ Институт ботаники им Н.Г. Холодного НАН Украины \\ ул. Терещенковская, 2, Киев 01601,Украина \\ e-mail: i_dudka@mail.ru \\ ${ }^{2}$ Харковская государственная зооветеринарная академия \\ ул. Академическая, 1, Малая Даниловка, Харьков 62341, Украина \\ e-mail: protista@mail.ru
}

В ходе микологического обследования буковых и пихтово-еловых коренных лесов на разных участках Карпатского биосферного заповедника, проведенного весной и осенью 2006 г., было выявлено 18 видов, две разновидности и одну форму миксомицетов. В систематическом отношении собранные виды миксомицетов распределились между порядками Protosteliales, Trichiales, Physarales, Liceales и Stemonitales. Наибольшим видовым разнообразием отличались порядок Trichiales и семейство Trichiaceae, представленные в коренных лесах семью видами и двумя разновидностями. Среди обнаруженных видов миксомицетов Metatrichia floriformis (Schwein.) Nann.-Bremek., собранная в буковом лесу Угольско-Широколужанского лесного масива (урочище Малая Уголька), является второй находкой для микобиоты Украины. Предыдущая находка была сделана профессором Львовского университета Г. Кшеменевской в лесах Черногорского массива в 1934 г. К другим редким видам миксомицетов из коренных лесов заповедника относится Fuligo intermedia T. Macbr., ранее известный в Украине только из двух находок на Левобережье (в национальном природном парке „Святые горы” и в Луганском природном заповеднике). Physarum robustum (Lister) Nann.-Bremek., 
найденный в пихтово-еловом лесу Черногоры возле полонины Брецкул, является новым видом для Украинских Карпат, а Trichia decipiens (Pers.) T. Macbr. var. olivacea Meyl. из букового леса Малой Угольки - новой разновидностью для Украинских Карпат. Проведен анализ субстратных предпочтений собранных миксомицетов. Установлено, что в условиях монодоминантных буковых лесов преобладающее большинство собранных мультисубстратных видов ассоциировано с мертвой древесиной Fagus sylvatica L.

Ключевые слова: Myxomycetes, слизевики, леса, видовое и таксономическое разнообразие, субстратные предпочтения.

Одержано: 24.01.2011 